\title{
The marine cyanobacterium Synechococcus sp. WH7805 requires urease (urea amidohydrolase, EC 3.5.1.5) to utilize urea as a nitrogen source: molecular-genetic and biochemical analysis of the enzyme
}

\author{
Jackie L. Collier, † Bianca Brahamsha and Brian Palenik \\ Author for correspondence: Jackie L. Collier. Tel : +1 518276 2178. Fax: +1518 2762162. \\ e-mail : collij3@rpi.edu
}

Marine Biology Research Division, Scripps Institution of Oceanography, University of California San Diego, La Jolla, CA 920930202, USA

\begin{abstract}
Cyanobacteria assigned to the genus Synechococcus are an important component of oligotrophic marine ecosystems, where their growth may be constrained by low availability of fixed nitrogen. Urea appears to be a major nitrogen resource in the sea, but little molecular information exists about its utilization by marine organisms, including Synechococcus. Oligonucleotide primers were used to amplify a conserved fragment of the urease (urea amidohydrolase, EC 3.5.1.5) coding region from cyanobacteria. A $5.7 \mathrm{kbp}$ region of the genome of the unicellular marine cyanobacterium Synechococcus Sp. strain WH7805 was then cloned, and genes encoding three urease structural subunits and four urease accessory proteins were sequenced and identified by homology. The WH7805 urease had a predicted subunit composition typical of bacterial ureases, but the organization of the WH7805 urease genes was unique. Biochemical characteristics of the WH7805 urease enzyme were consistent with the predictions of the sequence data. Physiological data and sequence analysis both suggested that the urease operon may be nitrogenregulated by the ntcA system in WH7805. Inactivation of the large subunit of urease, ureC, prevented WH7805 and Synechococcus WH8102 from growing on urea, demonstrating that the urease genes cloned are essential to the ability of these cyanobacteria to utilize urea as a nitrogen source.
\end{abstract}

Keywords: nitrogen assimilation, cyanobacterium, ammonium, nitrate, phytoplankton

\section{INTRODUCTION}

The unicellular cyanobacteria assigned to the genus Synechococcus (Waterbury \& Rippka, 1989) are an important component of the phytoplankton in many marine and freshwater planktonic ecosystems (Fogg, 1987; Waterbury et al., 1986). They contribute most significantly to total primary production in their most oligotrophic habitats (Chisholm, 1992; Fogg, 1987;

† Present address: Biology Department, Rensselaer Polytechnic Institute, 110 8th Street, Troy, NY 12180, USA

Abbreviations: GS, glutamine synthetase; RUBISCO, ribulose bisphosphate carboxylase-oxygenase.

The GenBank accession numbers for the sequences reported in this paper are AF065139 and AF056189.
Joint, 1986), such as those large oceanic regions where nitrogen availability is thought to limit primary productivity. The nitrogen utilized by the cyanobacteria and other primary producers in these regions appears to derive largely from the planktonic food-web-driven recycling of nitrogen from biomass into ammonium and urea (Dugdale \& Goering, 1967; Fogg, 1987; Hayward, 1991; Price \& Harrison, 1988). Urea, which is generally present in marine waters at levels of $0 \cdot 1-1 \mu \mathrm{M}$ (Antia $e t$ al., 1991), is formed by bacterial degradation of nucleic and amino acids and excreted by many animals as a waste product (McCarthy, 1980; Walsh, 1997). Urea is also the single dominant component of the diverse group of organic nitrogenous compounds known collectively as dissolved organic nitrogen that is present in the oligotrophic oceans at a total concentration of about $5 \mu \mathrm{M}$ (Antia et al., 1991). 
For all phytoplankton that have been examined except the Chlorophytes, urease is the enzyme responsible for decomposing urea (Leftley \& Syrett, 1973). Urease (urea amidohydrolase, EC 3.5.1.5) is a nickel-requiring metalloenzyme that catalyses the hydrolysis of urea, releasing two molecules of ammonia and one of carbonic acid from each urea molecule. Urease enzymes may be composed of one polypeptide $(840$ amino acid residues long in jack bean), or of two (238 and 569 amino acid residues long in Helicobacter strains) or three (approx. 100,100 , and 600 amino acid residues long in most bacteria) separate subunits. Whatever the subunit distribution, the sequences of urease structural genes are highly conserved (Mobley et al., 1995). In most bacteria, ure $A, u r e B$ and ure $C$ encode, respectively, the two small and one large structural subunits of the urease enzyme. The production of active urease also requires four accessory genes that are usually named ureD, ureE, ureF and $u r e G$. These genes encode proteins required for the assembly of the nickel metallocentre found at the urease active site (Mobley et al., 1995; Moncrief \& Hausinger, 1997). UreG sequences are almost as highly conserved as the urease structural genes, but UreD, UreE and UreF are more variable. All seven of the polypeptides required to produce active urease are usually found in one cluster in bacteria (Mobley et al., 1995). Urease is generally a cytoplasmic enzyme (Mobley \& Hausinger, 1989; Mobley et al., 1995), and the ammonium it releases from urea can therefore be assimilated directly by the organism. Urease may be expressed constitutively, or may be under many forms of regulation including global nitrogen status (ammonium repression), urea induction, or control by cell growth stage or by environmental factors such as $\mathrm{pH}$ (de Koning-Ward \& Robins-Browne, 1997; Mobley \& Hausinger, 1989).

The development of techniques to monitor the expression of urease in natural populations of marine phytoplankton would help to clarify the contribution that urea makes to their overall nitrogen nutrition, and improve our understanding of the role that urea plays in marine planktonic ecosystems. We have begun to approach this goal by investigating the genetic and biochemical basis of the utilization of urea as a nitrogen source by a model marine picophytoplankton, the unicellular cyanobacterium Synechococcus sp. strain WH7805.

\section{METHODS}

Strains and culture conditions. Marine Synechococcus isolate WH7805 was grown at $25^{\circ} \mathrm{C}$ with about $50 \mu \mathrm{mol}$ photons $\mathrm{m}^{-2}$ $\mathrm{s}^{-1}$ light from cool white fluorescent tubes on a shaking table in either modified SN or modified AN medium (Waterbury \& Willey, 1988). Six other axenic strains from the Woods Hole culture collection (WH7803, WH8102, WH8103, WH8011, WH8112 and WH8113; Waterbury et al., 1986) along with 15 new nonaxenic marine Synechococcus strains isolated from the California Current by B. Palenik (Toledo \& Palenik, 1997) were also examined. Both $\mathrm{AN}$ and $\mathrm{SN}$ were modified by substituting $\mathrm{FeCl}_{3}$ for ferric ammonium citrate, adding only vitamin $\mathrm{B}_{12}$ in place of the $\mathrm{Va}$ vitamin mix, and adding $\mathrm{NiCl}_{2}$ (final concentration $50 \mathrm{nM}$ ), $\mathrm{Na}_{2} \mathrm{SeO}_{3}$ (final concentration $10 \mathrm{nM}$ ) and $\mathrm{H}_{3} \mathrm{BO}_{3}$ (final concentration $16 \mu \mathrm{M}$ ) to the trace metals mix. Both types of media were prepared without any fixed nitrogen and sterilized by autoclaving. Routine monitoring by plating on $6 \mathrm{~g} \mathrm{l}^{-1}$ agar-solidified medium enriched with $5 \mathrm{~g}$ glucose $\mathrm{l}^{-1}$ and $0.5 \mathrm{~g}$ tryptone $\mathrm{l}^{-1}$ ensured the maintenance of axenic cultures of the WH strains. To provide a nitrogen source, either $1 \mathrm{mM} \mathrm{NaNO}, 1 \mathrm{mM} \mathrm{NH} \mathrm{mH}_{4} \mathrm{Cl}$, or $0.5 \mathrm{mM}$ urea was added from a filter-sterilized stock solution before each culture was inoculated. Stock cultures $(10 \mathrm{ml})$ were maintained in $18 \mathrm{~mm}$ culture tubes. Fifty-millilitre serial batch cultures for growth rate and urease regulation experiments were grown in $125 \mathrm{ml}$ Erlenmyer flasks plugged with cotton stoppers. These cultures were kept in exponential phase growth through six transfers by diluting $1 \mathrm{ml}$ of a culture nearing the end of exponential growth (less than $10^{8}$ cells $\mathrm{ml}^{-1}$ ) into $50 \mathrm{ml}$ fresh medium. Concentrations of ammonium, nitrate and urea in the cultures were determined by direct assays (Grasshoff et al., 1983). One-litre cultures for urease purification were grown in $2 \cdot 8$-litre Fernbach flasks. Cell densities were determined by epifluorescent cell counts in a hemacytometer at $400 \times$ magnification using a Zeiss Axioskop. Growth rates were also determined from the increase in chlorophyll absorbance at $680 \mathrm{~nm}\left(\mathrm{OD}_{680}\right)$, corrected for scattering at $750 \mathrm{~nm}\left(\mathrm{OD}_{750}\right)$ measured on a Perkin-Elmer Lambda 3B spectrophotometer.

Urease assay. Because WH7805 urease was somewhat unstable under conditions optimal for its activity, the enzyme was kept at suboptimal $\mathrm{pH}$ (buffer A; $25 \mathrm{mM}$ sodium/potassium phosphate, $\mathrm{pH} 7 \cdot 3$, plus $1 \mathrm{mM} \mathrm{Na}{ }_{2}$ EDTA) until it was assayed. Urease activity was measured by following the release of ammonium from urea. Generally $50 \mu \mathrm{l}$ crude cell extracts or purification fractions were added to $950 \mu$ l assay buffer $\left(100 \mathrm{mM} \mathrm{Na}_{2} \mathrm{HPO}_{4}\right)$ with $50 \mu \mathrm{l} 10 \mathrm{mM}$ urea $(500 \mu \mathrm{M}$ urea in the assay; final pH approximately 8.6$)$ and incubated at $25^{\circ} \mathrm{C}$ unless otherwise stated. At various times, $100 \mu \mathrm{l}$ was removed, added to $900 \mu \mathrm{l}$ freshly prepared MilliQ water, and the ammonium concentration in this sample determined by the indophenol method (Grasshoff $e t$ al., 1983). Urease activities were normalized to the total protein concentration of each sample, estimated using the Bio-Rad DC protein assay in microtitre plate format, and are reported here as 1 unit = $1 \mathrm{nmol}$ urea degraded $\mathrm{min}^{-1}$ (mg total protein $)^{-1}$. Whether urease was assayed in or purified from fresh cell pellets or from cells that were stored as pellets at $-80^{\circ} \mathrm{C}$ made no obvious difference to its properties or activity.

Purification of urease. Two types of localization experiments were performed on freshly harvested cells. Osmotic shock treatment was performed according to the procedure of Laudenbach et al. (1991). The high-EDTA treatment used to remove the outer membrane was performed as described by Brahamsha (1996a). For the purification of urease, 12 litres of exponential-phase WH7805 grown on nitrate was collected and stored at $-80^{\circ} \mathrm{C}$. The cell pellets were resuspended in $28 \mathrm{ml}$ buffer $\mathrm{A}$ and disrupted by three passes through a French pressure cell (Spectronic Instruments) at 20000 p.s.i. (138 $\mathrm{MPa})$ to produce the crude extract. Insoluble material and unbroken cells were removed by centrifugation at $50000 \mathrm{~g}$ for $45 \mathrm{~min}$ at $4^{\circ} \mathrm{C}$ to produce the $50000 \mathrm{~g}$ supernatant. The $50000 \mathrm{~g}$ supernatant was then heated to $60^{\circ} \mathrm{C}$ for $45 \mathrm{~min}$ with gentle mixing in a rotisserie hybridization oven. Heatinsoluble material was removed by centrifugation at $50000 \mathrm{~g}$ for $30 \mathrm{~min}$ at $4^{\circ} \mathrm{C}$, producing the heat supernatant. After storage at $4^{\circ} \mathrm{C}$ overnight, the volume of the heat supernatant was adjusted to $100 \mathrm{ml}$ with buffer $\mathrm{A}$, and the fraction precipitating between $20 \%$ and $35 \%$ saturation $\left(\mathrm{NH}_{4}\right)_{2} \mathrm{SO}_{4}$ 
was collected, dissolved in $8 \mathrm{ml}$ buffer $\mathrm{A}$, and dialysed overnight against two 1-litre volumes of buffer A to produce the ammonium sulfate cut fraction. The sample was then adjusted to $0.2 \mathrm{M} \mathrm{NaCl}$ in buffer $A$ and loaded onto a $1 \mathrm{ml}$ Pharmacia HiTrap Q Sepharose column by hand. The column was placed onto a GradiFrac and the salt concentration was increased linearly from $0.2 \mathrm{M}$ to $0.4 \mathrm{M} \mathrm{NaCl}$ in buffer $A$ over

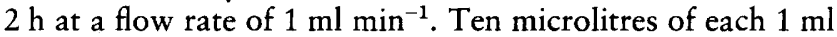
fraction was assayed to locate the peak of urease activity. Sixteen fractions containing the peak were combined and concentrated using Amicon Centricon-3 centrifugal concentrators to a volume of $1 \mathrm{ml}$ to produce the $\mathrm{Q}$ column peak fraction. This sample was then loaded onto a Pharmacia Sephacryl S-300 HR column running at a flow rate of $0.5 \mathrm{ml}$ $\min ^{-1}$. The five $1 \mathrm{ml}$ fractions (assayed as above) containing the peak of urease activity were combined and concentrated to a final volume of $1 \mathrm{ml}$, producing the $S 300$ column peak. The S-300 column was calibrated using the Pharmacia gel filtration HMW calibration kit. Fractions were analysed by SDS-PAGE on Novex 4-20\% polyacrylamide Tris-Glycine gels stained either with the Novex Colloidal Coomassie Staining Kit or with the Bio-Rad Silver Stain Plus Kit.

Cloning and sequencing. The deduced amino acid sequences of the 15 urease gene sequences present in GenBank in March 1994 were aligned using CLUSTAL v (Higgins et al., 1992). Oligonucleotides were designed to match the highly conserved regions found at residues 217-223 (KLHEDWG) and 315-322 (MLMVCHHL) of UreC in the similar alignment presented by Mobley et al. (1995). The sequences of the two primers were $5^{\prime}$ aagstscacgaggactgggg $3^{\prime}$ and $5^{\prime}$ aggtggtggcasaccatsagcat $3^{\prime}$. These primers should allow PCR-based amplification of a $317 \mathrm{bp}$ portion of the urease coding region from most ureases sequenced to date. A $100 \mu$ l reaction containing $1 \mu \mathrm{M}$ each primer, $2 \mathrm{mM} \mathrm{MgCl}_{2}, 200 \mu \mathrm{M}$ each dNTP, $0.5 \mu \mathrm{g}$ genomic DNA isolated from appropriate strains, 2 units Taq polymerase (Perkin-Elmer) and $1 \times$ Taq buffer was cycled 35 times with denaturing at $92{ }^{\circ} \mathrm{C}$ for $1 \mathrm{~min}$, annealing at $50^{\circ} \mathrm{C}$ for $1 \mathrm{~min}$, and extension at $72^{\circ} \mathrm{C}$ for $2 \mathrm{~min}$. The $317 \mathrm{bp}$ fragments produced from WH7805 and Anabaena sp. strain PCC 7120 by these primers were cloned using the Invitrogen TA cloning system and sequenced, confirming by their extensive homology with other ureases that they arose from a urease coding region. The sequence of the Anabaena PCC 7120 product has been deposited in GenBank under accession number AF065139. The WH7805 PCR fragment was then used as a probe for Southern analyses using the Boehringer Mannheim Genius system to identify overlapping $4.8 \mathrm{kbp} \mathrm{EcoRI} \mathrm{and} 5.4 \mathrm{kbp}$ PstI fragments covering a $9 \mathrm{kbp}$ region of the genome of WH7805 surrounding the PCR product. These fragments were cloned from size-selected pUC118 plasmid libraries via colony-lift hybridization to the PCR product (Sambrook et al., 1989), yielding plasmids pJC107 and pJC104, respectively. For sequencing, nested deletions were produced from these clones and from subclones in both orientations using the Promega Erase-a-Base kit. Gaps were filled in by sequencing from oligonucleotides synthesized commercially to serve as internal primers. Sequencing was performed using the ABI Prism cycle sequencing kit and protocol and an ABI 373 autosequencer. The entire $9 \mathrm{kbp}$ region was sequenced completely on both strands, sequences were proofread by hand, and no ambiguities remained. The $5.7 \mathrm{kbp}$ portion of the sequence reported here has been deposited in GenBank under accession number AF056189.

Inactivation of ureC in Synechococcus WH7805 and WH8102. ure $C$ was insertionally inactivated using a strategy described by Brahamsha (1996a). The 477 bp SphI-EcoRI fragment of the WH7805 ureC gene, which is completely internal to ure C, was subcloned from pJC107 using $S p h I$ (the resulting $S p h I$ fragment is 522 bp in length because the second $S p h I$ site is in the pUC118 polylinker, which also introduces a Pst site into the construct), and ligated into the $S p h I$ site of pMUT100. The resulting plasmid, pMUTjc1, was mobilized into Synechococcus sp. strains WH7805 and WH8102 as a suicide vector by conjugation using methods previously described (Brahamsha, 1996b). Exconjugants were selected on SN pour plates containing kanamycin $\left(25 \mu \mathrm{g} \mathrm{ml}^{-1}\right)$ and were screened by Southern blot hybridization to confirm that the restriction pattern was indicative of integration of pMUTjc1 at the site of homology. Urease activity levels and the ability of the transconjugants to utilize nitrate $(5 \mathrm{mM})$, ammonium $(2 \mathrm{mM})$ or urea $(1 \mathrm{mM})$ as sole nitrogen source were assessed as described above and compared to the wild-type strains WH7805 and WH8102.

\section{RESULTS}

\section{Growth of WH7805 on nitrate, ammonium and urea}

Urea, ammonium and nitrate could each be utilized as the sole nitrogen source supporting growth of Synechococcus WH7805 (Fig. 1). The long-term suitability of these nitrogen sources was confirmed by the maintenance of stock WH7805 cultures for more than 12 passages on media containing only one of the three compounds as sole nitrogen source. Each of the three nitrogen sources also supported the growth of the 15 nonaxenic marine Synechococcus isolates from the California Current (Toledo \& Palenik, 1997) tested, as well as five of the six other axenic isolates from the WH culture collection (Waterbury et al., 1986) tested. The single exception was Synechococcus sp. strain WH7803, which could use either ammonium or nitrate but not urea. Closer inspection of the growth rate of WH7805 in serial batch cultures, which were kept in exponential phase through six transfers and never allowed to exhaust

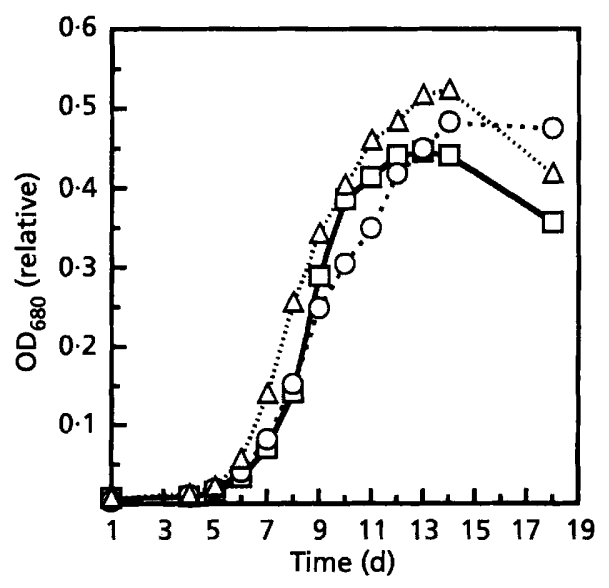

Fig. 1. Growth of Synechococcus WH7805 cultures utilizing different nitrogen sources. Changes in the chlorophyll absorbance $(680 \mathrm{~nm})$ of representative batch cultures that started with $1 \mathrm{mM}$ nitrate $(0) .1 \mathrm{mM}$ ammonium ( $\square$ ) or $0.5 \mathrm{mM}$ urea $(\triangle)$ as the sole nitrogen source and were allowed to grow to stationary phase are shown. 


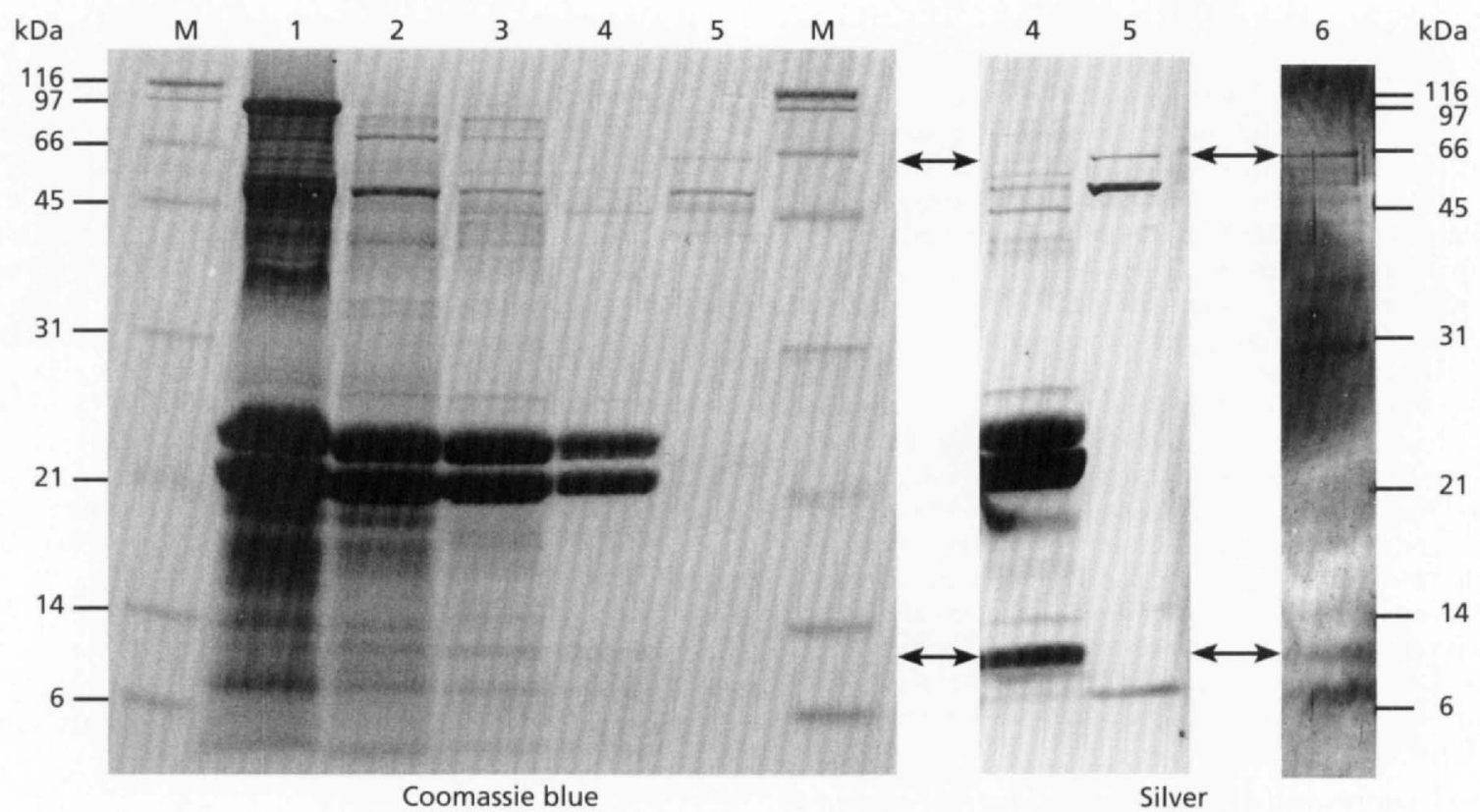

Fig. 2. SDS-PAGE analysis of the partial purification of WH7805 urease. M, markers (molecular masses to the left and right of the figure); 1 , crude extract; $2,50000 \mathrm{~g}$ supernatant; 3 , heat supernatant; 4 , ammonium sulfate cut; $5, Q$ column peak; 6,5300 column peak. The gel on the left was stained with Coomassie blue, and both gels on the right were silverstained. For fractions $1,2,3$ and $4,0.03 \%$ of the urease activity was loaded; for fractions 5 and $6,1.5 \%$ and $4.5 \%(50$ and 150 times more than the initial fractions, respectively) of the urease activity was loaded. The arrows indicate the putative 11 and $60 \mathrm{kDa}$ urease subunit bands (see text).

Table 1. Summary of the partial purification of urease from WH7805

Activity is given in units of nmol urea hydrolysed $\mathrm{min}^{-1}$. See text for a detailed description of each step in the procedure.

\begin{tabular}{|lccccc|}
\hline Purification step & $\begin{array}{c}\text { Total } \\
\text { protein } \\
(\mathbf{m g})\end{array}$ & $\begin{array}{c}\text { Total } \\
\text { activity } \\
\text { (units) }\end{array}$ & $\begin{array}{c}\text { Recovery } \\
(\% \text { initial } \\
\text { activity) }\end{array}$ & $\begin{array}{c}\text { Specific } \\
\text { activity [units } \\
\text { (mg total } \\
\left.\text { protein })^{-1}\right]\end{array}$ & $\begin{array}{c}\text { Purification } \\
\text { factor }\end{array}$ \\
\hline $\begin{array}{l}\text { Crude extract } \\
50000 \boldsymbol{g}\end{array}$ & $139 \cdot 6$ & 2308 & 100 & $16 \cdot 5$ & 1 \\
$\quad$ supernatant & $61 \cdot 2$ & 1883 & $81 \cdot 6$ & $30 \cdot 8$ & $1 \cdot 9$ \\
$\begin{array}{l}\text { Heat supernatant } \\
\text { Ammonium sulfate }\end{array}$ & $47 \cdot 1$ & 1829 & $79 \cdot 2$ & $38 \cdot 8$ & $2 \cdot 4$ \\
$\quad$ cut & $18 \cdot 9$ & 992 & 43 & $52 \cdot 5$ & $3 \cdot 2$ \\
$\begin{array}{l}\text { Q column peak } \\
\text { S300 column peak }\end{array}$ & $0 \cdot 28$ & 312 & $13 \cdot 5$ & 1132 & $68 \cdot 6$ \\
\hline
\end{tabular}

their supply of nitrogen to less than $0.2 \mathrm{mM}$, showed that the three nitrogen sources were not entirely equivalent. For the last two transfers (which were representative of the first four), ammonium-grown cells exhibited doubling times of 18.7 and $19.5 \mathrm{~h}$, with urease activities of 3.2 and 3.5 units, respectively. Urea-grown cells had similar growth rates, doubling in 18.3 and $20.2 \mathrm{~h}$, but $50 \%$ higher urease activity levels of 5.7 and 4.3 units, respectively. Nitrate-grown cells exhibited $15 \%$ slower growth, doubling in 21.0 and $22.8 \mathrm{~h}$, along with fivefold higher urease activity levels of 22 and 14 units, respectively.

\section{Biochemical characterization of WH7805 urease activity}

Experiments performed during development of the purification protocol described below defined several biochemical characteristics of the WH7805 urease. Urease activity was generally higher in disrupted than in 
(a)

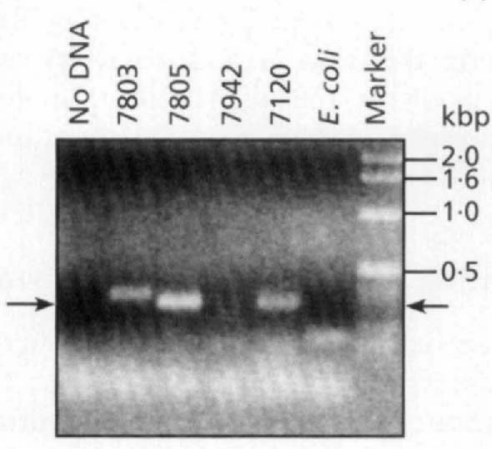

78037805

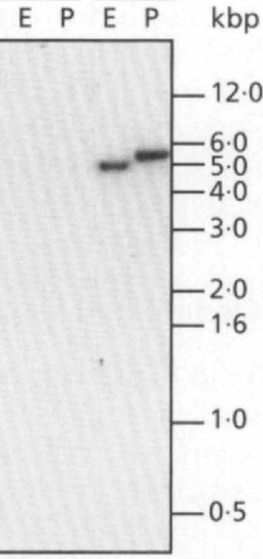

(c)

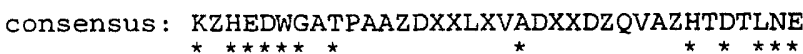
SYNC7805: KLHEDWGTTPATIDACLSVADRMDVQVCIHTDTLNE ANAB7120: KLHEDWGTTPATIDTCLTVADEYDVQVAIHTDTLNE SYNY6803: KLHEDWGTTPAAIDNCLGVAEDYDVQVAIHTDTLNE

consensus: XGFVEDTXXAXXGRTIHTYHTEGAGGGHAPDZIXXX SYNC7805: AGFVEDTIAAIKGRTIHTFHTEGAGGGHAPDIIKIC ANAB7120: AGFVEDTIAAFKNRAIHTYHTEGAGGGHAPDIIKVC SYNY6803: AGFVETTIAALKNRVIHTYHTEGAGGGHAPDIIKIC

consensus: GXXNZLPSSTNPTXPYTXNTXXEHXDMZMVCHHL SYNC7805: GEANVLPSSTNPTRPYTRNTLEEHLDMLMVCHHL ANAB7120: GQANVLPSSTNPTRPYTVNTLDEHLDMLMVCHHL SYNY6803: GELNVLPSSTNPTRPYTINTLEEHLDMLMVCHHL

(d) $1 \mathrm{kbp}$

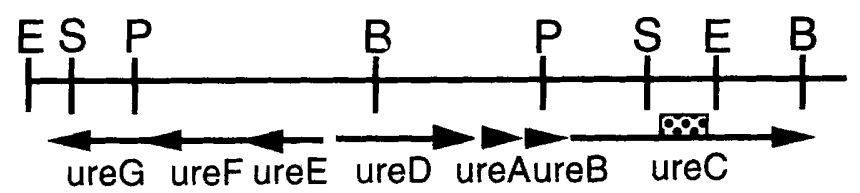
L pJC107 intact cells, suggesting that the urease was localized intracellularly rather than on the cell surface. In experiments performed to yield optimal cell breakage, no detectable activity was found in the high-speed membrane pellet from cells disrupted by treatment with lysozyme followed by sonication, and less than $1 \%$ of the initial urease activity was found in the high-speed membrane pellet of cells disrupted by passage through a French pressure cell, showing that the urease activity of WH7805 was soluble. Two experiments suggested that the urease activity of WH7805 was cytoplasmic rather than periplasmic. After osmotic shock, only $14 \%$ of the initial activity was released while $86 \%$ remained with the cells, and after removal of the outer cell membrane by treatment with EDTA (Brahamsha, 1996a) no detectable activity was released from the cells. Only one peak of urease activity, with an apparent molecular mass of $420 \mathrm{kDa}$, was identified in extracts subjected to size-exclusion chromatography on both Sephacryl S-300 and $\mathrm{S}-400$ resins. The $\mathrm{pH}$ optimum for urea degradation in crude extracts of WH7805 was found to be $8 \cdot 6$, with less than half of maximal activity remaining at $\mathrm{pH} 7.6$ or 9.6. No preference for $\mathrm{Na}^{+}$or $\mathrm{K}^{+}$counterions in the phosphate buffer system used was detected, and no other buffer systems tested (including carbonate and Tris) gave different results or higher activities. The initial rates of urea degradation were measured at urea concentrations in the range $10-1000 \mu \mathrm{M}$, and suggested that the WH7805 urease activity displayed simple Michaelis-Menten saturation kinetics with a $K_{m}$ of $232 \mu \mathrm{M}\left(r^{2}=0.997\right)$.

Most organisms use the enzyme urease to degrade urea, but Chlorophytes and some yeasts are known to use instead an ATP- and biotin-dependent urea amidolyase pathway (EC 3.5.1.45). The two activities may be distinguished by several biochemical characteristics, including differential sensitivity to inhibitors and different requirements for optimal activity (Leftley $\&$ Syrett, 1973). Two lines of evidence supported the hypothesis that the urea-degrading activity measured in WH7805 was due to the presence of urease rather than the urea amidolyase pathway. First, only a moderate (less than $50 \%$ ) stimulation of urea-degrading activity was observed in the presence of ATP at concentrations up to $100 \mu \mathrm{M}$, and a decline in activity at higher ATP levels was observed (data not shown). A similar moderate stimulation was also observed in the presence of up to $1 \mathrm{mM}$ EDTA, suggesting that in both cases chelation of inhibitory metal ions might be responsible for the stimulation of urease activity, as has been suggested previously for algal ureases (Leftley \& Syrett, 1973). Second, as with most ureases (Mobley \& Hausinger, 1989), the urease activity of WH7805 was moderately

EcoRl; S, Sphl; P, Pstl; B, BamHI. The locations and orientations of the urease genes are indicated by arrows labelled with the gene name. The location of the $317 \mathrm{bp}$ fragment of urec amplified by PCR is marked by the dotted box. The portions of the region originally cloned in pJC107 and pJC104 are indicated below the map. 
(a)

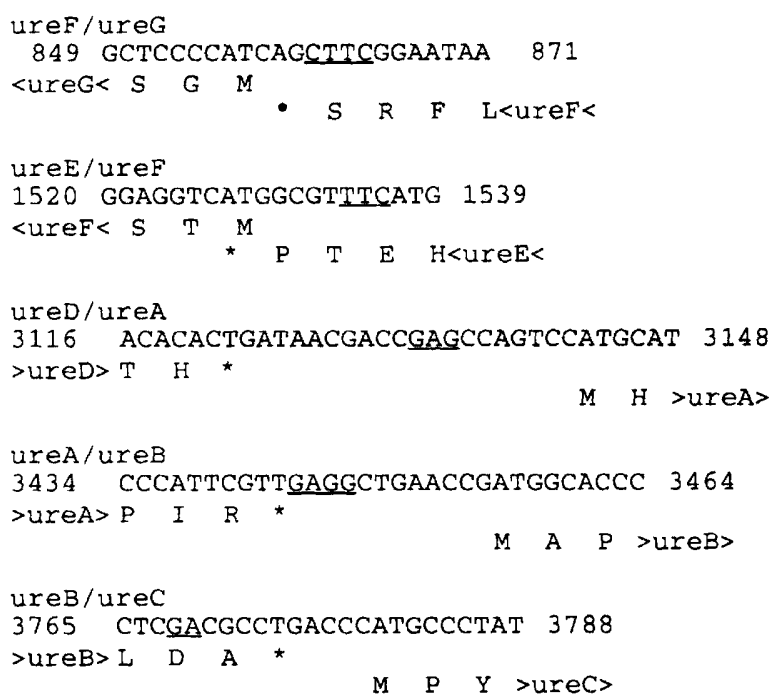

Fig. 4. Sequences between the ure open reading frames in WH7805. (a) Regions between the closely spaced and overlapping ure genes. (b) The putative divergent promoter region between ure $E$ and $u r e D$. Nucleotide sequences are given from $5^{\prime}$ to $3^{\prime}$ in the same orientation and with the same numbering system as used in the map in Fig. 3(d) and in GenBank accession number AF056189. Potential ribosomebinding sites are underlined and the potential NtcA-binding site is double underlined.

heat stable. It had a broad temperature optimum from 40 to $55^{\circ} \mathrm{C}$, where it was over twice as active as it was near the WH7805 growth temperature optimum of 20 to $25^{\circ} \mathrm{C}$. The WH7805 urease was inactivated by temperatures higher than $55^{\circ} \mathrm{C}$; it was stable for about $2 \mathrm{~h}$ at $60^{\circ} \mathrm{C}$, but lost half of its activity within $30 \mathrm{~min}$ at $70^{\circ} \mathrm{C}$ and within $10 \mathrm{~min}$ at $80^{\circ} \mathrm{C}$.

\section{Partial purification of the WH7805 urease enzyme}

A five-step purification protocol resulted in an 80-fold purification of WH7805 urease activity (Table 1, Fig. 2). Ribulose bisphosphate carboxylase-oxygenase (RUBISCO) and glutamine synthetase (GS), both identified by $\mathrm{N}$-terminal sequencing, were two of the most difficult contaminants to remove from urease. The heat treatment was most effective in the removal of RUBISCO, while size-exclusion chromatography was most effective in the removal of GS (approx. $50 \mathrm{kDa}$ bands in samples 2 versus 3 and 5 versus 6, respectively, in Fig. 2). The phycobiliproteins were effectively removed by the ion- exchange chromatography step (samples 4 versus 5, Fig. 2). Significant amounts of urease protein or activity or both were lost in each of the last three steps. In the S300 column peak, $7 \%$ of the total urease activity was recovered with $0.08 \%$ of the initial protein. This final fraction produced a number of bands on a silver-stained SDS-PAGE gel (sample 6, Fig. 2).

\section{Cloning and sequencing of the WH7805 urease genes}

Two highly conserved regions around the urease active site were chosen as targets for oligonucleotides (see Methods). PCR using these degenerate oligonucleotides as primers yielded a fragment of the predicted size of 317 bp from WH7805 and Anabaena sp. strain PCC 7120 genomic DNA (Fig. 3a), as well as from all other urealytic marine Synechococcus later tested (data not shown). No amplification products were observed from non-urealytic organisms such as the freshwater cyanobacterium Synechococcus sp. strain PCC 7942 or Escherichia coli DH5 $\alpha$ (Fig. 3a). The non-urealytic marine Synechococcus sp. strain WH7803 produced a larger product than expected (Fig. 3a); sequencing of the WH7803 PCR product revealed that it did not arise from urease, and its amplification was subsequently eliminated by modifying the conditions of the PCR reaction. Southern analysis using the PCR product from WH7805 as a probe suggested that the PCR product from WH7805 arose from a single-copy target in its genome and also showed that a similar region was lacking from the WH7803 genome (Fig. 3b). The sequences of the PCR products from WH7805 and from the heterocystous, dinitrogen-fixing cyanobacterium Anabaena sp. strain PCC 7120 confirmed that these products did arise from urease (Fig. 3c).

The WH7805 PCR product was used as a probe to identify and clone overlapping $5.4 \mathrm{kbp} \mathrm{Pst} \mathrm{a}$ and $4.8 \mathrm{kbp}$ EcoRI fragments from the genome of WH7805 (Fig. 3b), generating pUC118-based plasmids pJC104 and pJC107, respectively. A map of the entire EcoRI fragment plus the adjacent 900 bp of the Pst I fragment is shown in Fig. 3 (d). Seven open reading frames in this region were identified by homology to urease structural subunits and accessory genes already sequenced from a variety of bacteria, and this region appeared to encode all of the functions needed to produce active urease (Mobley et al., 1995). ure A, ure $B$ and ure $C$ encoded the structural subunits of the urease enzyme, and were similar in sequence and arrangement to the urease structural subunits of most other bacteria. All of the residues thought to be essential for urease activity (Jabri et al., 1995) were present in the WH7805 ureABC genes. The predicted molecular masses of UreA and UreB were both $11 \mathrm{kDa}$, and that of UreC was $60 \mathrm{kDa}$. These predicted subunit sizes corresponded to the estimated molecular masses of two bands enriched during the partial purification of WH7805 urease (Fig. 2). ureD, ureE, ureF and $u r e G$ were predicted to encode proteins that are similar in both size $(35,19,24$ and $22 \mathrm{kDa}$, respectively) and sequence to previously analysed homologues 
(Mobley et al., 1995). A P-loop motif thought to be essential to the function of UreG (Moncrief \& Hausinger, 1997) was conserved in WH7805. The histidinerich region at the C-terminus of UreE thought to be important for nickel binding (Brayman \& Hausinger, 1996) was of moderate length in WH7805. As in many other bacteria, ureE, ureF and ure $G$ were contiguous, as were ure $A$, ureB and ureC. However, in WH7805 these two groups of genes were uniquely arranged, with ureEFG in the opposite orientation from ureDABC. The coding regions of $u r e E$ and $u r e F$ as well as $u r e F$ and $u r e G$ overlapped (Fig. 4a), suggesting that these accessory proteins were translationally coupled and formed an operon. While the coding regions of ureD and ure $A$, $u r e A$ and $u r e B$, and $u r e B$ and $u r e C$ did not overlap, they were closely spaced (Fig. 4a), suggesting that they may also form an operon. The two groups of genes were separated by a small region that may contain a divergent promoter and an NtcA-binding site imparting global nitrogen regulatory control to the urease genes (Fig. $4 \mathrm{~b}$ ). No known urease-related genes were identified in the $3 \cdot 3$ kbp sequenced downstream of ureC (data not shown); the region downstream of $u r e G$ has not yet been explored.

Codon usage in the urease genes of WH7805 taken together (ureABCDEFG) was generally similar to that reported for eight genes from the closely related strain Synechococcus WH7803 (Table 2, and Carr \& Mann, 1994). Among the WH7805 ure genes, ureA, ureB and ure $C$ exhibited third-codon position preference in the order $\mathrm{C}>\mathrm{G}>\mathrm{T} \geqslant \mathrm{A}$ and had a third-position $\mathrm{G}+\mathrm{C}$ content of $77.2,77.6$ and $81.9 \mathrm{~mol} \%$, respectively; ureE, ureF and ure $G$ exhibited third-codon preference in the order $\mathrm{G}>\mathrm{C}>\mathrm{T}>\mathrm{A}$ and had a third-position $\mathrm{G}+\mathrm{C}$ content of $68.2,70.5$ and $69.7 \mathrm{~mol} \%$, respectively. ureD did not clearly belong to either group, exhibiting thirdcodon position preference $\mathrm{C}>\mathrm{G}>\mathrm{A}>\mathrm{T}$ and a thirdposition $\mathrm{G}+\mathrm{C}$ content of $72.8 \mathrm{~mol} \%$. Table 2 summarizes the codon usage for ure $A B C$, ureEFG and ureD. Differences in codon usage between ure $A B C$ and $u r e E F G$ occurred in several cases (e.g. Phe, Pro, Ala, Asp, Glu, Cys); in some cases ureD was more similar to ure $A B C$ (e.g. Ala, Cys, Glu), but in others it was more like ureEFG (e.g. Asp) or distinct from either group (e.g. Phe, Pro). Differences in codon bias and nucleotide content among the urease genes of WH7805 could reflect differences in their expression levels (Berg \& Silva, 1997; Wilbanks \& Glazer, 1993), although there is no direct evidence of the relative expression levels of the urease genes in WH7805. Differences in base composition might also reflect genome-scale influences driven by the opposite orientation of ureDABC versus ureEFG (Freeman et al., 1998).

\section{Inactivation of ureC}

To determine whether the urease structural genes identified in this study were required for the ability of marine Synechococcus to utilize urea as sole nitrogen source, the ureC gene was inactivated in two strains,
WH7805 and WH8102, by interrupting its coding sequence via homologous recombination between the chromosome and a completely internal ureC fragment from WH7805 carried by a suicide vector, pMUTjc1 (see Methods). To verify that integration had taken place at the target site and that no wild-type copies of ure C remained in the transconjugants, chromosomal DNA isolated from the mutants was digested with PstI and probed with the $522 \mathrm{bp} \mathrm{SphI}$ fragment of pMUTjc1. The $5.4 \mathrm{kbp}$ PstI fragment present in wild-type WH7805 was completely absent in the transconjugants (Fig. 5), even following overexposure of the Southern blot. It was replaced by two hybridizing fragments of 6.3 and $1.35 \mathrm{kbp}$, which agreed well with the fragment sizes of 6.1 and $1.3 \mathrm{kbp}$ expected to result from integration of the suicide vector, carrying a new Pst I site, at the region of homology on the chromosome. Similarly, in WH8102 the wild-type $2.7 \mathrm{kbp}$ fragment was completely replaced in the mutants by two hybridizing fragments of 1.35 and $3.3 \mathrm{kbp}$ (Fig. 5).

Both parental strains, Synechococcus WH7805 and WH8102, were capable of growth with $1 \mathrm{mM}$ urea as sole nitrogen source, but transconjugant strains 23-A, $-B,-C$ and $-D$ derived from WH7805 as well as 23-1 and -2 derived from WH8102 were not able to use urea as sole nitrogen source. The ability of these strains to grow utilizing either ammonium or nitrate as sole nitrogen source was unimpaired. Additionally, urease activity was normal in the parental strains but undetectable in the transconjugant strains. These results indicate that ure $\mathrm{C}$ is required both for urease activity and for growth on urea by Synechococcus sp. strains WH7805 and WH8102, and that the ability to degrade urea is not required for growth on either nitrate or ammonium. Furthermore, these results indicate that despite differences in restriction fragment patterns in the wild-type strains, recombination can occur between the ureC genes of these two strains of marine Synechococcus.

\section{DISCUSSION}

Urea provides a useable nitrogen source for many, but not all, cyanobacteria (Berns et al., 1966; Kapp et al., 1975; Kratz \& Myers, 1955; McLachlan \& Gorham, 1962). Among the marine Synechococcus surveyed in this study, only WH7803, which otherwise appears closely related to WH7805 (Palenik, 1994; Waterbury et al., 1986), was unable to utilize urea. Contrary to a previous report (Waterbury et al., 1986), WH8113, WH8011 and WH8103 each grew well with urea as the sole nitrogen source under the growth conditions used here. The region of ureC targeted for PCR amplification was present in all urea-utilizing cyanobacterial strains tested, but was lacking in the two strains (WH7803 and the freshwater Synechococcus strain PCC 7942) that could not use urea. Southern blots hybridized with a $1.25 \mathrm{kbp}$ fragment from the opposite end of pJC104 (leaving a $2 \mathrm{kbp}$ gap between the C-terminus of ureC and the $1.25 \mathrm{kbp}$ probe) revealed that WH7803 lacked not only the small region of $u r e C$ targeted by our PCR 
Table 2. Codon usage in the urease-encoding (ureABC) and accessory (ureDEFG) genes of Synechococcus WH7805

For each combination of coding regions, the raw number of occurrences of each codon is given, followed by the percentage utilization of that codon among its synonyms.

\begin{tabular}{|c|c|c|c|c|c|c|c|c|c|}
\hline \multirow{2}{*}{$\begin{array}{l}\text { Amino } \\
\text { acid }\end{array}$} & \multirow[t]{2}{*}{ Codon } & \multicolumn{2}{|c|}{ ure $A B C D E F G$} & \multicolumn{2}{|c|}{ ure $A B C$} & \multicolumn{2}{|c|}{ ure $D$} & \multicolumn{2}{|c|}{ ureEFG } \\
\hline & & No. & $\%$ & No. & $\%$ & No. & $\%$ & No. & $\%$ \\
\hline \multirow[t]{2}{*}{ Phe } & TTT & 14 & $30 \cdot 4$ & 3 & 11.5 & 3 & 37.5 & 8 & $66 \cdot 7$ \\
\hline & TTC & 32 & $69 \cdot 6$ & 23 & 88.5 & 5 & $62 \cdot 5$ & 4 & $33 \cdot 3$ \\
\hline \multirow{6}{*}{ Leu } & TTA & 3 & 1.4 & 0 & 0.0 & 1 & $2 \cdot 3$ & 2 & $2 \cdot 0$ \\
\hline & TTG & 48 & $22 \cdot 7$ & 7 & $10 \cdot 1$ & 5 & $11 \cdot 6$ & 36 & $36 \cdot 4$ \\
\hline & CTT & 21 & $10 \cdot 0$ & 7 & $10 \cdot 1$ & 2 & $4 \cdot 7$ & 12 & $12 \cdot 1$ \\
\hline & CTC & 41 & $19 \cdot 4$ & 23 & $33 \cdot 3$ & 8 & 18.6 & 10 & $10 \cdot 1$ \\
\hline & CTA & 8 & 3.8 & 0 & 0.0 & 4 & $9 \cdot 3$ & 4 & $4 \cdot 0$ \\
\hline & CTG & 90 & $42 \cdot 7$ & 32 & $46 \cdot 4$ & 23 & $53 \cdot 5$ & 35 & $35 \cdot 4$ \\
\hline \multirow[t]{3}{*}{ Ile } & ATT & 18 & $24 \cdot 0$ & 11 & $21 \cdot 6$ & 1 & $14 \cdot 3$ & 6 & $35 \cdot 3$ \\
\hline & ATC & 56 & $74 \cdot 4$ & 39 & 76.5 & 6 & 85.7 & 11 & $64 \cdot 7$ \\
\hline & ATA & 1 & $1 \cdot 3$ & 1 & $2 \cdot 0$ & 0 & 0.0 & 0 & 0.0 \\
\hline Met & ATG & 31 & 100 & 18 & 100 & 3 & 100 & 10 & 100 \\
\hline \multirow[t]{4}{*}{ Val } & GTT & 7 & $6 \cdot 2$ & 3 & 5.7 & 1 & 5.9 & 3 & $7 \cdot 0$ \\
\hline & GTC & 18 & 15.9 & 8 & $15 \cdot 1$ & 5 & $29 \cdot 4$ & 5 & 11.6 \\
\hline & GTA & 1 & 0.9 & 0 & 0.0 & 1 & 5.9 & 0 & 0.0 \\
\hline & GTG & 87 & $77 \cdot 0$ & 42 & $79 \cdot 2$ & 10 & 58.8 & 35 & $81 \cdot 4$ \\
\hline \multirow[t]{6}{*}{ Ser } & TCT & 4 & 3.9 & 1 & $3 \cdot 0$ & 0 & 0.0 & 3 & $6 \cdot 5$ \\
\hline & TCC & 21 & $20 \cdot 4$ & 8 & $24 \cdot 2$ & 4 & $16 \cdot 7$ & 9 & $19 \cdot 6$ \\
\hline & TCA & 6 & $5 \cdot 8$ & 0 & $0 \cdot 0$ & 2 & $8 \cdot 3$ & 4 & 8.7 \\
\hline & TCG & 14 & $13 \cdot 6$ & 4 & $12 \cdot 1$ & 2 & $8 \cdot 3$ & 8 & $17 \cdot 4$ \\
\hline & AGT & 12 & $11 \cdot 7$ & 3 & $9 \cdot 1$ & 2 & $8 \cdot 3$ & 7 & $15 \cdot 2$ \\
\hline & AGC & 46 & $44 \cdot 7$ & 17 & $51 \cdot 5$ & 14 & $58 \cdot 3$ & 15 & $32 \cdot 6$ \\
\hline \multirow[t]{4}{*}{ Pro } & CCT & 8 & $8 \cdot 3$ & 2 & $4 \cdot 4$ & 3 & 16.7 & 3 & $9 \cdot 1$ \\
\hline & CCC & 43 & $44 \cdot 8$ & 30 & $66 \cdot 7$ & 5 & 27.8 & 8 & $24 \cdot 2$ \\
\hline & $\mathrm{CCA}$ & 11 & $11 \cdot 5$ & 0 & 0.0 & 5 & 27.8 & 6 & 18.2 \\
\hline & CCG & 34 & $35 \cdot 4$ & 13 & 28.9 & 5 & 27.8 & 16 & 48.5 \\
\hline \multirow[t]{4}{*}{ Thr } & $\mathrm{ACT}$ & 6 & 6.7 & 3 & $5 \cdot 4$ & 1 & $7 \cdot 1$ & 2 & $10 \cdot 0$ \\
\hline & $\mathrm{ACC}$ & 56 & $62 \cdot 2$ & 41 & $73 \cdot 2$ & 5 & 35.7 & 10 & $50 \cdot 0$ \\
\hline & $\mathrm{ACA}$ & 8 & 8.9 & 2 & $3 \cdot 6$ & 5 & 35.7 & 1 & $5 \cdot 0$ \\
\hline & ACG & 20 & $22 \cdot 2$ & 10 & 17.9 & 3 & 21.4 & 7 & 35.0 \\
\hline \multirow[t]{4}{*}{ Ala } & GCT & 39 & 21.8 & 11 & 13.8 & 6 & $19 \cdot 4$ & 22 & $32 \cdot 4$ \\
\hline & GCC & 92 & $51 \cdot 4$ & 57 & $71 \cdot 3$ & 18 & $58 \cdot 1$ & 17 & $25 \cdot 0$ \\
\hline & GCA & 15 & $8 \cdot 4$ & 6 & $7 \cdot 5$ & 2 & $6 \cdot 5$ & 7 & $10 \cdot 3$ \\
\hline & GCG & 33 & 18.4 & 6 & 7.5 & 5 & $16 \cdot 1$ & 22 & $32 \cdot 4$ \\
\hline \multirow[t]{2}{*}{ Tyr } & TAT & 7 & $36 \cdot 8$ & 2 & $25 \cdot 0$ & 2 & $66 \cdot 7$ & 3 & 37.5 \\
\hline & TAC & 12 & $63 \cdot 2$ & 6 & $75 \cdot 0$ & 1 & $33 \cdot 3$ & 5 & $62 \cdot 5$ \\
\hline \multirow[t]{3}{*}{ Stop } & TAA & 0 & 0.0 & 0 & 0.0 & 0 & 0.0 & 0 & 0.0 \\
\hline & TAG & 0 & 0.0 & 0 & 0.0 & 0 & 0.0 & 0 & 0.0 \\
\hline & TGA & 7 & 100 & 3 & 100 & 1 & 100 & 3 & 100 \\
\hline \multirow[t]{2}{*}{ His } & CAT & 16 & 30.8 & 6 & $25 \cdot 0$ & 3 & $27 \cdot 3$ & 7 & $41 \cdot 2$ \\
\hline & CAC & 36 & $69 \cdot 2$ & 18 & $75 \cdot 0$ & 8 & $72 \cdot 7$ & 10 & 58.8 \\
\hline \multirow{2}{*}{ Gln } & $\mathrm{CAA}$ & 20 & 27.8 & 4 & $15 \cdot 4$ & 9 & $42 \cdot 9$ & 7 & 28 \\
\hline & CAG & 52 & $72 \cdot 2$ & 22 & $84 \cdot 6$ & 12 & $57 \cdot 1$ & 18 & 72 \\
\hline \multirow[t]{2}{*}{ Asn } & AAT & 14 & $31 \cdot 1$ & 8 & $34 \cdot 8$ & 1 & $9 \cdot 1$ & 5 & 45.5 \\
\hline & AAC & 31 & $68 \cdot 9$ & 15 & $65 \cdot 2$ & 10 & $90 \cdot 9$ & 6 & $54 \cdot 5$ \\
\hline Lys & AAA & 16 & $38 \cdot 1$ & 10 & 37.0 & 3 & $50 \cdot 0$ & 3 & $33 \cdot 3$ \\
\hline & AAG & 26 & $61 \cdot 9$ & 17 & $63 \cdot 0$ & 3 & $50 \cdot 0$ & 6 & $66 \cdot 7$ \\
\hline Asp & GAT & 32 & $36 \cdot 4$ & 8 & 17.8 & 6 & $50 \cdot 0$ & 18 & 58.1 \\
\hline & GAC & 56 & 63.6 & 37 & $82 \cdot 2$ & 6 & $50 \cdot 0$ & 13 & $41 \cdot 9$ \\
\hline
\end{tabular}


Table 2. (cont.)

\begin{tabular}{|c|c|c|c|c|c|c|c|c|c|}
\hline \multirow{2}{*}{$\begin{array}{l}\text { Amino } \\
\text { acid }\end{array}$} & \multirow[t]{2}{*}{ Codon } & \multicolumn{2}{|c|}{ ure $A B C D E F G$} & \multicolumn{2}{|c|}{ ure $A B C$} & \multicolumn{2}{|c|}{ ureD } & \multicolumn{2}{|c|}{ ureEFG } \\
\hline & & No. & $\%$ & No. & $\%$ & No. & $\%$ & No. & $\%$ \\
\hline \multirow[t]{2}{*}{ Glu } & GAA & 52 & $49 \cdot 1$ & 31 & $64 \cdot 6$ & 12 & $70 \cdot 6$ & 9 & 22 \\
\hline & GAG & 54 & $50 \cdot 9$ & 17 & $35 \cdot 4$ & 5 & $29 \cdot 4$ & 32 & 78 \\
\hline \multirow[t]{2}{*}{ Cys } & TGT & 8 & $30 \cdot 8$ & 2 & $20 \cdot 0$ & 1 & $14 \cdot 3$ & 5 & $55 \cdot 6$ \\
\hline & TGC & 18 & $69 \cdot 2$ & 8 & $80 \cdot 0$ & 6 & $85 \cdot 7$ & 4 & $44 \cdot 4$ \\
\hline $\operatorname{Trp}$ & TGG & 26 & 100 & 7 & 100 & 9 & 100 & 10 & 100 \\
\hline \multirow[t]{6}{*}{ Arg } & CGT & 16 & $12 \cdot 9$ & 2 & $4 \cdot 5$ & 2 & 6.5 & 12 & $24 \cdot 5$ \\
\hline & CGC & 65 & $52 \cdot 4$ & 28 & $63 \cdot 6$ & 19 & $61 \cdot 3$ & 18 & $36 \cdot 7$ \\
\hline & CGA & 10 & $8 \cdot 1$ & 5 & $11 \cdot 4$ & 1 & $3 \cdot 2$ & 4 & $8 \cdot 2$ \\
\hline & CGG & 26 & $21 \cdot 0$ & 6 & $13 \cdot 6$ & 7 & $22 \cdot 6$ & 13 & $26 \cdot 5$ \\
\hline & $\mathrm{AGA}$ & 1 & 0.8 & 1 & $2 \cdot 3$ & 0 & 0.0 & 0 & $0 \cdot 0$ \\
\hline & $\mathrm{AGG}$ & 6 & $4 \cdot 8$ & 2 & $4 \cdot 5$ & 2 & $6 \cdot 5$ & 2 & $4 \cdot 1$ \\
\hline \multirow[t]{4}{*}{ Gly } & GGT & 24 & $15 \cdot 5$ & 11 & $13 \cdot 4$ & 3 & $11 \cdot 5$ & 10 & $21 \cdot 3$ \\
\hline & GGC & 86 & $55 \cdot 5$ & 57 & $69 \cdot 5$ & 14 & $53 \cdot 8$ & 15 & 31.9 \\
\hline & GGA & 17 & $11 \cdot 0$ & 4 & 4.9 & 4 & $15 \cdot 4$ & 9 & $19 \cdot 1$ \\
\hline & GGG & 28 & $18 \cdot 1$ & 10 & $12 \cdot 2$ & 5 & $19 \cdot 2$ & 13 & $27 \cdot 7$ \\
\hline Sum & & 1706 & & 778 & & 320 & & 608 & \\
\hline
\end{tabular}

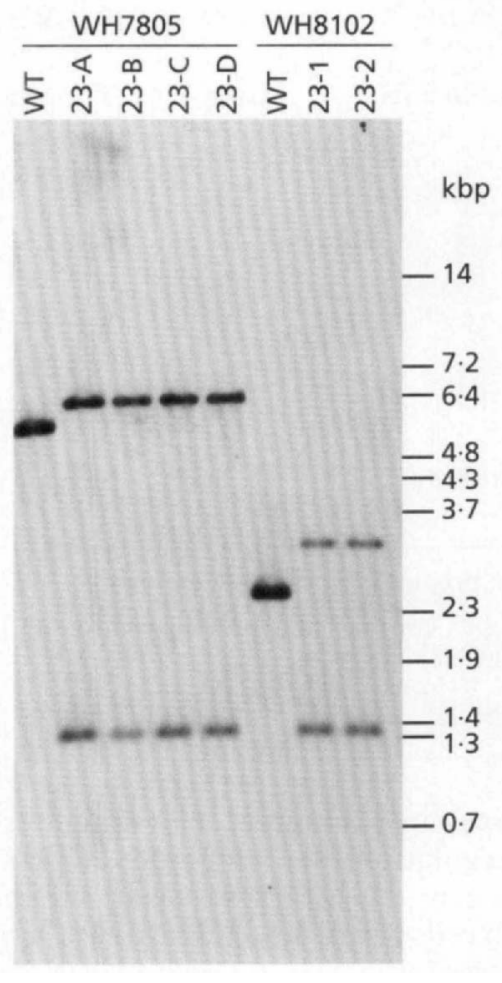

Fig. 5. Southern analysis of ureC-inactivated Synechococcus strains. Genomic DNA isolated from the wild-type (WT) or transconjugants of pMUTjc1 in Synechococcus sp. strains WH7805 and WH8102 was digested with Pstl. The probe was the $522 \mathrm{bp} \mathrm{Sphl}$ fragment of pMUTjc1 comprising $477 \mathrm{bp}$ of ure $C$ and 45 bp of polylinker from pUC118, which includes a new Pstl site. The migration of size standards is indicated on the right. primers, but also a region of several kbp downstream of the urease gene cluster. It is not known whether the absence of urease is characteristic of some wild cyanobacterial strains, or reflects changes in the genomes of strains such as PCC 7942 and WH7803 that have occurred since they were brought into culture. Similar to Synechococcus WH7805 and WH8102, wild-type Synechococcus sp. strain PCC 7002 can utilize urea or nitrate as its sole nitrogen source, but ureC-inactivated derivatives of PCC 7002 lose the ability to utilize urea while retaining the ability to grow on nitrate (Sakamoto et al., 1998). Although urease appears to be nonessential for both naturally occurring (PCC 7942, WH7803) and genetically engineered (WH7805, WH8102, PCC 7002) urease-negative Synechococcus growing on nitrate or ammonium in culture, urease may play other roles in cellular metabolism, such as internal nitrogen recycling, that are beneficial to these organisms under natural conditions.

The urea-utilizing cyanobacteria examined to date have been reported to possess a nickel-requiring urea amidohydrolase (EC 3.5.1.5) that is soluble and cytoplasmic (Berns et al., 1966; Ge et al., 1990; Mackerras \& Smith, 1986; Rai \& Singh, 1987; Singh, 1990, 1991, 1993). The $\mathrm{pH}$ and temperature optima for WH7805 urease are toward the upper and lower ends, respectively, of the range reported for other cyanobacterial ureases (Table 3). The $K_{\mathrm{m}}$ value estimated here for WH7805 urease is within the range reported for most other cyanobacterial ureases (Table 3), which tend to have a higher affinity for urea than the ureases of many other bacteria (Mobley \& Hausinger, 1989). Given that urea concentrations in the sea rarely exceed $1 \mu \mathrm{M}$, and that urease in WH7805 is cytoplasmic, it is likely that 
Table 3. Summary of cyanobacterial ureases

\begin{tabular}{|c|c|c|c|c|c|c|c|}
\hline Organism & $\begin{array}{c}\text { Native } \\
\text { mol. } \\
\text { mass } \\
(\mathrm{kDa})\end{array}$ & $\begin{array}{l}\text { Subunit } \\
\text { mol. mass } \\
(\mathrm{kDa})^{*}\end{array}$ & $\boldsymbol{K}_{\mathrm{m}}\langle\boldsymbol{\mu} \mathbf{M}\rangle$ & $\begin{array}{l}\mathrm{pH} \text { (and } \\
\text { temp.) } \\
\text { optimum }\end{array}$ & $\begin{array}{l}\text { Crude specific } \\
\text { activity }(\mathrm{nU}) \dagger\end{array}$ & Regulation $\neq$ & Reference \\
\hline \multirow{2}{*}{$\begin{array}{r}\text { Anabaena } \\
\text { doliolum }\end{array}$} & 228 & 36 & 115 & $7\left(40^{\circ} \mathrm{C}\right)$ & 240 & & Rai (1989) \\
\hline & & & 120 & $7-7 \cdot 4\left(40^{\circ} \mathrm{C}\right)$ & $\begin{array}{c}3.8(\mathrm{~A}) \text { to } 10.5(\mathrm{U}) \\
0.7(\mathrm{~A}) \text { to } 7(\mathrm{U})\end{array}$ & GNR & $\begin{array}{l}\text { Rai \& Singh (1987) } \\
\text { Singh (1990) }\end{array}$ \\
\hline \multirow{2}{*}{$\begin{array}{l}\text { Anabaena } \\
\text { cylindrica }\end{array}$} & 197 & 32 & & $8\left(30^{\circ} \mathrm{C}\right)$ & $3 \cdot 2$ & & Argall et al. (1992) \\
\hline & & & 1300 & & 16 to 58 & $\mathrm{C}$ & $\begin{array}{l}\text { Mackerras \& Smith } \\
(1986)\end{array}$ \\
\hline $\begin{array}{l}\text { Spirulina } \\
\text { maxima }\end{array}$ & 232 & 38 & 120 & $8 \cdot 7$ & 210 & & Carvajal et al. (1982) \\
\hline $\begin{array}{l}\text { Leptolyngbya } \\
\text { boryana }\end{array}$ & 220 & $66,18,11$ & 250 & $8 \cdot 2\left(60^{\circ} \mathrm{C}\right)$ & 120 & $\mathrm{C}$ & Jahns et al. (1995) \\
\hline $\begin{array}{l}\text { Anabaena } \\
\text { PCC } 7120\end{array}$ & 220 & $66,14,11$ & 250 & $8.5\left(65^{\circ} \mathrm{C}\right)$ & 80 & $\mathrm{C}$ & Jahns et al. (1995) \\
\hline $\begin{array}{l}\text { Anabaena } \\
\text { variabilis }\end{array}$ & & & 46 & & $0 \cdot 8$ & C & Ge et al. (1990) \\
\hline \multirow{3}{*}{$\begin{array}{l}\text { Anacystis } \\
\text { nidulans } \\
\text { ATCC } 27144\end{array}$} & & & & & $25(\mathrm{~N})$ to $200(-\mathrm{N})$ & GNR & Singh (1991) \\
\hline & & & & & & & \\
\hline & & & $\begin{array}{l}250,1660 \\
\text { (biphasic) }\end{array}$ & $7-7 \cdot 4\left(40^{\circ} \mathrm{C}\right)$ & $3 \cdot 6(\mathrm{~A})$ to $10(\mathrm{U})$ & GNR & Rai \& Singh (1987) \\
\hline $\begin{array}{l}\text { Synechococcus } \\
\text { WH7805 }\end{array}$ & 420 & $(60,11,11)$ & 232 & $8.6\left(45^{\circ} \mathrm{C}\right)$ & $3.5(\mathrm{~A})$ to $16.5(\mathrm{~N})$ & GNR & This study \\
\hline $\begin{array}{l}\text { Synechocystis } \\
\text { PCC } 6803\end{array}$ & & $(61,11,11)$ & & & & & Kaneko et al. (1996) \\
\hline $\begin{array}{l}\text { Plectonema } \\
\text { calothricoides }\end{array}$ & & & & & 115 & & Berns et al. (1966) \\
\hline $\begin{array}{l}\text { Synechococcus } \\
\text { lividus }\end{array}$ & & & & & 75 & & Berns et al. (1966) \\
\hline $\begin{array}{l}\text { Phormidium } \\
\text { luridum }\end{array}$ & & & & & 30 & & Berns et al. (1966) \\
\hline $\begin{array}{l}\text { Nostoc } \\
\text { muscorum }\end{array}$ & & & & & $0.6(\mathrm{~A})$ to $9.8(\mathrm{U})$ & GNR & Singh (1993) \\
\hline
\end{tabular}

* Values were determined biochemically except for those in parentheses, which were predicted from DNA sequences.

†Crude specific activity is given in nmol urea hydrolysed $\min ^{-1}\left(\mathrm{mg}\right.$ protein) ${ }^{-1}(\mathrm{nU})$. (A), cultures grown with ammonium; (N), cultures grown with nitrate; $(\mathrm{U})$, cultures grown with urea; $(-\mathrm{N})$, nitrogen-deprived cultures.

$\ddagger C$, constitutive expression; GNR; global nitrogen regulation (ammonium; repression).

WH7805 also possesses a high-affinity urea-transport system. Crude specific activities for cyanobacterial ureases range from 0.6 to $240 \mathrm{nmol}$ urea hydrolysed $\min ^{-1}$ (mg protein $)^{-1}$ (Table 3 ). Assuming that each WH7805 cell contains approximately $50 \mathrm{fg}$ nitrogen (Kana \& Glibert, 1987) and $500 \mathrm{fg}$ protein (Kramer \& Morris, 1990), the level of urease activity measured at $25^{\circ} \mathrm{C}$ in urea-grown WH7805 doubling approximately once per day is sufficient to supply its estimated nitrogen needs. In several cyanobacteria, urease activity is invariant during growth on different nitrogen sources, suggesting that urease may be constitutively expressed in these organisms (Table 3). In other cyanobacteria, urease activity varies during growth on different ni- trogen sources in a manner suggesting that urease is subject to regulation by ammonium repression via the global nitrogen regulatory system, although ammonium-grown cells retain detectable urease activity (Table 3 ). The differences in urease activity levels reported here for WH7805 growing on different nitrogen sources suggest that urease expression in WH7805 may also exhibit (incomplete) ammonium repression via the global nitrogen regulatory system. Since ammonium concentrations in the sea rarely exceed $1 \mu \mathrm{M}$, it appears likely that WH7805 would always possess some urease activity in its natural habitat. Whether this is characteristic of marine Synechococcus in general remains to be established. 
In contrast to the general agreement among the biochemical properties of diverse cyanobacterial ureases, some data regarding their physical structures are in conflict. Leptolyngbya boryanum and Anabaena sp. strain PCC 7120 have been reported to possess typical microbial ureases with an alpha subunit of $66 \mathrm{kDa}$, a beta subunit of 14 or $18 \mathrm{kDa}$, and a gamma subunit of $11 \mathrm{kDa}$ (Jahns et al., 1995), similar to the subunit sizes reported here for Synechococcus sp. strain WH7805. The apparent native molecular mass of the Leptolyngbya boryanum and Anabaena PCC 7120 enzymes is $220 \mathrm{kDa}$, approximately $20 \%$ below the predicted value for a heterotrimeric (UreAUreBUreC) ${ }_{3}$ quaternary structure similar to Klebsiella aerogenes (K. pneumoniae) urease (Jabri et al., 1995; Mobley \& Hausinger, 1989). The apparent native molecular mass of WH7805 urease was more consistent with a heterohexameric (UreAUreBUreC) $)_{6}$ structure that yields a predicted native molecular mass of $497 \mathrm{kDa}, 15 \%$ above the measured value of $420 \mathrm{kDa}$. Reports of both trimeric and hexameric structures for ureases are not unusual; both trimers and hexamers of jack bean urease are active (Mobley et al., 1995), and other bacteria have been reported to possess hexameric ureases of similar native size to that from WH7805 (Mobley \& Hausinger, 1989). More significant discrepancies have arisen with regard to the unique subunit structures reported for the ureases of the cyanobacteria Spirulina maxima, Anabaena doliolum and Anabaena cylindrica (Argall et al., 1992; Carvajal et al., 1982; Mackerras \& Smith, 1986; Rai, 1989; Singh, 1990, 1991), which appear to comprise homohexamers of a single 32 to $38 \mathrm{kDa}$ subunit (Table 3). Argall et al. (1992) were also unable to detect hybridization of a urease gene probe from $K$. aerogenes to genomic DNA of Anabaena cylindrica. However, given the difference in $\mathrm{G}+\mathrm{C}$ content between these two organisms (60 versus $40 \mathrm{~mol} \%$, respectively), failure of this cross-hybridization does not provide conclusive evidence that amino acid level similarity between their urease genes is low. Although Anabaena cylindrica was not tested, the primers developed for this study were capable of amplifying the targeted fragment of ure C from Anabaena PCC 7120 (Fig. 3). Additionally, the sequence of the Synechocystis PCC 6803 genome (Kaneko et al., 1996) shows that it possesses seven urease genes similar to those found in WH7805, and Synechococcus PCC 7002 possesses at least ureC (Sakamoto et al., 1998). It appears likely that the incongruent biochemical data from Spirulina maxima, Anabaena doliolum and Anabaena cylindrica reflect the difficulties inherent in purifying some microbial ureases (the presence of a prominent $30 \mathrm{kDa}$ band in Fig. 2 may represent just such an artifact), and that further work will confirm that all cyanobacteria do possess typical bacterial ureases like that found in WH7805.

Close spacing and overlapping of ure reading frames is also observed in other urease gene clusters (Jones \& Mobley, 1989; Lee et al., 1992; Maeda et al., 1994). However, the split of WH7805 urease genes into one ure $\mathrm{DABC}$ cluster and a divergent ureEFG cluster is unique among microbial ureases sequenced to date, which are more commonly grouped as ureDABCEFG or ure ABCEFGD (Neyrolles et al., 1996). Proteus mirabilis does have a divergent regulatory gene, ureR (Island \& Mobley, 1995). Other cyanobacteria present even more unusual arrangements. The urease genes of Synechocystis PCC 6803 (Kaneko et al., 1996) are completely unclustered and are scattered throughout its genome. Similarly, the ureC gene of Synechococcus PCC 7002 appears to be encoded separately from other urease genes (Sakamoto et al., 1998). Closer examination of cyanobacterial ureases may reveal new models for the regulation and coordination of urease gene expression and enzyme assembly.

Although the divergent promoter region between $u r e E$ and ureD in WH7805 is novel among urease gene clusters, divergent promoters themselves are a common phenomenon (Beck \& Warren, 1988), perhaps with important roles in providing control over the coordination and relative levels of expression of the genes on either side. The pattern of urease activity observed in WH7805 grown on different nitrogen sources suggests the possibility that urease is regulated by ammonium repression via $n t c A$ as part of the global nitrogen regulatory system that is common among cyanobacteria (Frias et al., 1993). The consensus sequence GTAN $\mathrm{N}_{8}$ TAC is generally found in the -35 position relative to transcription initiation (Muro-Pastor et al., 1996) in $\mathrm{NtcA}$-regulated genes. Near the middle of the $112 \mathrm{bp}$ separating the start codons of ureE and ureD in WH7805 is the sequence GTGN $_{8}$ TAC, which is identical to a proposed NtcA-binding site located upstream of a nitrogen-regulated promoter for $n t c A$ itself in the closely related strain Synechococcus sp. strain WH7803 (Lindell et al., 1998). However, the WH7805 ure divergent promoter region may be too small to allow the position of this site to represent $a-35$ region for either or both of $u r e E$ and $u r e D$; if it does represent an NtcA-binding site involved in regulating the expression of the WH7805 urease gene cluster, it may use a different mechanism. The sequence TTGATT is found inside of and just outside of the potential NtcA-binding site, and some short, complementary sequences [TCCCCN ${ }_{9}$ GAGC versus GCTCN ${ }_{14}$ GGGGA] can be found upstream of each translation initiation site (Fig. $4 \mathrm{~b}$ ). The relevance of any of these sequences to the transcription, translation or regulation of the urease genes in WH7805 has yet to be established.

\section{ACKNOWLEDGEMENTS}

This work was supported by NSF OCE-9521535 to J.L.C., by DOE DE-FG03-93ER61692 to B.P., and by NSF MCB9418842 to B.B. We thank Tiffany Nguyen for technical assistance with the heat-stability experiments, and other members of the Palenik and Brahamsha labs for valuable assistance in many other aspects of this work. Sequencing was performed at the SIO Automated Sequencing Facility. We also thank John Waterbury for sharing the WH marine Synechococcus strains, along with two anonymous reviewers and the editor for their help in improving this manuscript. 


\section{REFERENCES}

Antia, N. J., Harrison, P. J. \& Oliveira, L. (1991). The role of dissolved organic nitrogen in phytoplankton nutrition, cell biology and ecology. Phycologia 30, 1-89.

Argall, M. E., Smith, G. D., Stamford, N. P. J. \& Youens, B. N. (1992). Purification and properties of urease from the cyanobacterium Anabaena cylindrica. Biochem Int 27, 1027-1036.

Beck, C. F. \& Warren, R. A. J. (1988). Divergent promoters, a common form of gene organization. Microbiol Rev 52, 318-326.

Berg, O. G. \& Silva, P. J. N. (1997). Codon bias in Escherichia coli: the influence of codon context on mutation and selection. Nucleic Acids Res 25, 1397--1404.

Berns, D. S., Holohan, P. \& Scott, E. (1966). Urease activity in bluegreen algae. Science 152, 1077-1078.

Brahamsha, B. (1996a). An abundant cell-surface polypeptide is required for swimming by the nonflagellated marine cyanobacterium Synechococcus. Proc Natl Acad Sci USA 93, 6504-6509.

Brahamsha, B. (1996b). A genetic manipulation system for oceanic cyanobacteria of the genus Synechococcus. Appl Environ Microbiol 62, 1747-1751.

Brayman, T. G. \& Hausinger, R. P. (1996). Purification, characterization, and functional analysis of a truncated Klebsiella aerogenes UreE urease accessory protein lacking the histidine-rich carboxyl terminus. J Bacteriol 178, 5410-5416.

Carr, N. G. \& Mann, N. H. (1994). The oceanic cyanobacterial picoplankton. In The Molecular Biology of Cyanobacteria, pp. 27-48. Edited by D. A. Bryant. Dordrecht: Kluwer.

Carvajal, N., Fernandez, M., Rodriguez, J. P. \& Donoso, M. (1982). Urease of Spirulina maxima. Phytochemistry 21, 2821-2823.

Chisholm, S. W. (1992). Phytoplankton size. In Primary Productivity and Biogeochemical Cycles in the Sea, pp. 213-237. Edited by P. G. Falkowski \& A. D. Woodhead. New York: Plenum.

Dugdale, R. C. \& Goering, J. J. (1967). Uptake of new and regenerated forms of nitrogen in primary productivity. Limnol Oceanogr 12, 196-206.

Fogg, G. E. (1987). Marine planktonic cyanobacteria. In The Cyanobacteria, pp. 393-414. Edited by P. Fay \& C. Van Baalen. Amsterdam: Elsevier.

Freeman, J. M., Plasterer, T. N., Smith, T. F. \& Mohr, S. C. (1998), Patterns of genome organization in bacteria. Science 279, 1827a.

Frias, J. E., Merida, A., Herrero, A., Martin-Nieto, J. \& Flores, E. (1993). General distribution of the nitrogen control gene $n t c A$ in cyanobacteria. J Bacteriol 175, 5710-5713.

Ge, X., Cain, K. \& Hirschberg, R. (1990). Urea metabolism and urease regulation in the cyanobacterium Anabaena variabilis. Can J Microbiol 36, 218-222.

Grasshoff, K., Ehrhardt, M. \& Kremling, K. (1983). Methods of Seawater Analysis. Weinheim: Verlag Chemie.

Hayward, T. L. (1991). Primary productivity in the north Pacific central gyre: a controversy with important implications. Trends Ecol Evol 6, 281-284.

Higgins, D. G., Bleasby, A. J. \& Fuchs, R. (1992). CLuSTAL-V improved software for multiple sequence alignment. Comput Appl Biosci 8, 189-191.

Island, M. D. \& Mobley, H. L. T. (1995). Proteus mirabilis urease: operon fusion and linker insertion analysis of ure gene organization, regulation, and function. J Bacteriol 177, 5653-5660.

Jabri, E., Carr, M. B., Hausinger, R. P. \& Karplus, P. A. (1995). The crystal structure of urease from Klebsiella aerogenes. Science $\mathbf{2 6 8}$, 998-1004.

Jahns, T., Schafer, U. \& Kaltwasser, H. (1995). Heat-stable ureases from two filamentous cyanobacteria. Microbiology 141, 737-741.

Joint, I. R. (1986). Physiological ecology of picoplankton in various oceanographic provinces. Can J Fish Aquat Sci 214, 287-309.

Jones, B. D. \& Mobley, H. T. (1989). Proteus mirabilis urease: nucleotide sequence determination and comparison with jack bean urease. J Bacteriol 171, 6414-6422.

Kana, T. M. \& Glibert, P. M. (1987). Effect of irradiances up to $2000 \mu \mathrm{E} \mathrm{m}^{-2} \mathrm{~s}^{-1}$ on marine Synechococcus WH7803-I. Growth, pigmentation, and cell composition. Deep-Sea Res 34, 479-495.

Kaneko, T., Sato, S., Kotani, H. \& 21 other authors (1996). Sequence analysis of the genome of the unicellular cyanobacterium Synechocystis sp. strain PCC6803. II. Sequence determination of the entire genome and assignment of potential protein-coding regions. DNA Res 3, 109-136.

Kapp, R., Stevens, S. E., Jr \& Fox, J. L. (1975). A survey of available nitrogen sources for the growth of the blue-green alga, Agmenellum quadruplicatum. Arch Microbiol 104, 135-138.

de Koning-Ward, T. F. \& Robins-Browne, R. M. (1997). A novel mechanism of urease regulation in Yersinia enterocolitica. FEMS Microbiol Lett 147, 221-226.

Kramer, J. G. \& Morris, I. (1990). Growth regulation in irradiance limited marine Synechococcus sp. WH 7803. Arch Microbiol 154, 286-293.

Kratz, W. A. \& Myers, J. (1955). Nutrition and growth of several blue-green algae. Am J Bot 42, 282-287.

Laudenbach, D. E., Ehrhardt, D., Green, L. \& Grossman, A. R. (1991). Isolation and characterization of a sulfur-regulated gene encoding a periplasmically localized protein with sequence similarity to rhodanese. J Bacteriol 173, 2751-2760.

Lee, M. H., Mulrooney, S. B., Renner, M. J., Markowicz, Y. \& Hausinger, R. P. (1992). Klebsiella aerogenes urease gene cluster: sequences of ureD and demonstration that four accessory genes (ureD, ureE, ureF, and ure G) are involved in nickel metallocenter biosynthesis. J Bacteriol 174, 4624-4330.

Leftley, J.W. \& Syrett, P. J. (1973). Urease and ATP:urea amidolyase activity in unicellular algae. J Gen Microbiol 77, 109-115.

Lindell, D., Padan, E. \& Post, A. F. (1998). Regulation of $n t c A$ expression and nitrite uptake in the marine Synechococcus sp. strain WH 7803. J Bacteriol 180, 1878-1886.

McCarthy, J. J. (1980). Nitrogen. In The Physiological Ecology of Phytoplankton, pp. 191-233. Edited by I. Morris. Berkeley: University of California Press.

Mackerras, A. H. \& Smith, G. D. (1986). Urease activity of the cyanobacterium Anabaena cylindrica. J Gen Microbiol 132, 2749-2752.

McLachlan, J. \& Gorham, P. R. (1962). Effects of pH and nitrogen sources on growth of Microcystis aeruginosa Kütz. Can J Microbiol 8, 1-11.

Maeda, M., Hidaka, M., Nakamura, A., Masaki, H. \& Uozumi, T. (1994). Cloning, sequencing, and expression of the thermophilic Bacillus sp. strain TB-90 urease gene complex in Escherichia coli. $J$ Bacteriol 176, 432-442.

Mobley, H. T. \& Hausinger, R.P. (1989). Microbial ureases: significance, regulation, and molecular characterization. Microbiol Rev 53, 85-108. 
Mobley, H. T., Island, M. D. \& Hausinger, R. P. (1995). Molecular biology of microbial ureases. Microbiol Rev 59, 451-480.

Moncrief, M. B. C. \& Hausinger, R. P. (1997). Characterization of UreG, identification of a UreD-UreF-UreG complex, and evidence suggesting that a nucleotide-binding site in UreG is required for in vivo metallocenter assembly of Klebsiella aerogenes urease. $J$ Bacteriol 179, 4081-4086.

Muro-Pastor, M. I., Reyes, J. C. \& Florencio, F. J. (1996). The $\mathrm{NADP}^{+}$-isocitrate dehydrogenase gene $(i c d)$ is nitrogen regulated in cyanobacteria. J Bacteriol 178, 4070-4076.

Neyrolles, O., Ferris, S., Behbahani, N., Montagnier, L. \& Blanchard, A. (1996). Organization of Ureaplasma urealyticum urease gene cluster and expression in a suppressor strain of Escherichia coli. J Bacteriol 178, 647-655.

Palenik, B. (1994). Cyanobacterial community structure as seen from RNA polymerase gene sequence analysis. $J$ Bacteriol 60 , 3212-3219.

Price, N. M. \& Harrison, P. J. (1988). Urea uptake by Sargasso Sea phytoplankton: saturated and in situ uptake rates. Deep-Sea Res 35, 1579-1593.

Rai, A. K. (1989). Purification and properties of urease from a cyanobacterium Anabaena doliolum. FEMS Microbiol Lett 61, 319-322.

Rai, A. K. \& Singh, S. (1987). Urease of blue-green algae (Cyanobacteria) Anabaena doliolum and Anacystis nidulans. Curr Microbiol 16, 113-117.

Sakamoto, T., Delgaizo, V. B. \& Bryant, D. A. (1998). Growth on urea can trigger death and peroxidation of the cyanobacterium Synechococcus sp. strain PCC 7002. Appl Environ Microbiol 64, 2361-2366.

Sambrook, J., Fritsch, E. F. \& Maniatis, T. (1989). Molecular Cloning: a Laboratory Manual, 2nd edn. Cold Spring Harbor, NY: Cold Spring Harbor Laboratory.
Singh, S. (1990). Regulation of urease activity in the cyanobacterium Anabaena doliolum. FEMS Microbiol Lett 67, 79-84.

Singh, S. (1991). Role of nickel and N-starvation in the regulation of urea metabolism in the cyanobacterium Anacystis nidulans. $J$ Gen Appl Microbiol 37, 325-330.

Singh, S. (1993). Role of glutamine synthetase, glutamine and $\mathrm{NH}_{4}^{+}$in regulation of urea metabolism in cyanobacterium, Nostoc muscorum. Indian J Exp Biol 31, 256-259.

Toledo, G. \& Palenik, B. (1997). Synechococcus diversity in the California Current as seen by RNA polymerase (rpoC1) gene sequences of isolated strains. Appl Environ Microbiol 63, $4298-4303$.

Walsh, P. J. (1997). Evolution and regulation of urea synthesis and ureotely in (Batrachoidid) fishes. Annu Rev Physiol 59, 299-323.

Waterbury, J. B. \& Rippka, R. (1989). Subsection I. Order Chroococcales Wettstein 1924, emend. Rippka et al., 1979. In Bergey's Manual of Systematic Bacteriology, pp. 1728-1746. Edited by J. T. Staley, M. P. Bryant, N. Pfennig \& J. G. Holt. Baltimore: Williams \& Wilkins.

Waterbury, J. B. \& Willey, J. M. (1988). Isolation and growth of marine planktonic cyanobacteria. Methods Enzymol 197, 100105.

Waterbury, J. B., Watson, S. W., Valois, F. W. \& Franks, D. G. (1986). Biological and ecological characterization of the marine unicellular cyanobacterium Synechococcus. Can J Fish Aquat Sci 214, 71-120.

Wilbanks, S. M. \& Glazer, A. N. (1993). Rod structure of a phycoerythrin II-containing phycobilisome. I. Organization and sequence of the gene cluster encoding the major phycobiliprotein rod components in the genome of marine Synechococcus sp. WH8020. J Biol Chem 268, 1226-1235.

Received 29 June 1998; revised 21 September 1998; accepted 20 October 1998. 